\title{
Pharmacokinetics and pharmacodynamics of fluoroquinolones in the respiratory tract
}

\author{
R. Wise*, D. Honeybourne**
}

Pharmacokinetics and pharmacodynamics of fluoroquinolones in the respiratory tract. $R$. Wise, D. Honeybourne. (C)ERS Journals Ltd 1999.

ABSTRACT: Pharmacokinetic and pharmacodynamic features are important predictors of the therapeutic efficacy of an antibiotic. In respiratory tract infection, study of the clinical implication of pharmacodynamic features is complicated as infection occurs at several distinct sites. To ensure microbiological efficacy, antibiotics should not only be active against common respiratory pathogens but should also penetrate to the sites of infection.

The newer fluoroquinolones combine good activity against Gram-negative and "atypical" organisms with extended Gram-positive activity, and are unaffected by penicillin susceptibility status and $\beta$-lactamase production. Long terminal half-lives allow once-or twice-daily dosing, and a concentration in lung tissue at levels many times higher than is observed in the serum.

Although the benefit of antibiotics in some lower respiratory tract infections has been questioned, they have proved effective in community-acquired pneumonia and acute exacerbations of chronic obstructive pulmonary disease. Early studies of oral fluoroquinolones versus intravenous or oral treatment with one or more agents in community-acquired pneumonia have shown promise. Although resistance is a potential problem with increased fluoroquinolone use, its rapid development is not anticipated.

In conclusion, the broad-spectrum antimicrobial activity, tissue distribution and safety profile of fluoroquinolones suggest that they have a place in respiratory tract infection.

Eur Respir J 1999; 14: 221-229.
*Dept of Medical Microbiology, City Hospital NHS Trust, Birmingham, UK. **Dept of Respiratory Medicine, Birmingham Heartlands Hospital, Birmingham, UK.

\section{Correspondence: R. Wise}

Dept of Medical Microbiology

City Hospital NHS Trust

Birmingham

$\mathrm{B} 187 \mathrm{QH}$

UK

Fax: 441215517763

Keywords: Fluoroquinolones lower respiratory tract infection pharmacodynamics pharmacokinetics tissue penetration

Received: October 211998

Accepted after revision March 71999
Lower respiratory tract infection is a common condition associated with considerable morbidity and mortality. Chronic bronchitis affects over 1 million individuals in the UK, with an estimated 7 million sufferers in the USA [1]. Community-acquired pneumonia is also common, though data regarding the incidence and associated morbidity and mortality of this nonreportable disease are difficult to assimilate. The management of lower respiratory tract infection is complicated by the increasingly recognized spectrum of pathogens associated with this disease and their antibiotic susceptibility patterns. Disease management guidelines for respiratory tract infection are a relatively recent occurrence [2-4].

Pathogens commonly associated with lower respiratory tract infection include Haemophilus influenzae, Streptococcus pneumoniae and Moraxella catarrhalis, with atypical organisms playing a significant aetiological role in pneumonia. Increasing antibiotic resistance in these pathogens has led to concerns about the efficacy of currently available antibiotics. S. pneumoniae isolates from around the world are displaying increasing resistance to penicillin and other antibiotics [5], while $\beta$-lactamase production is seen in $>90 \%$ of clinical $M$. catarrhalis isolates in the USA and is forecast in $\sim 50 \%$ of $H$. influenzae isolates by the year 2000 [6]. In mainland Europe, rates of pneumococcal $\beta$-lactam resistance are rising, with the highest incidences in Spain ( 35\%), France and Portugal (20\%). Macrolide resistance is also increasing, with a correlation being found between the local prevalence of penicillin and macrolide resistance in many countries. For example, in Spain the association between macrolide resistance in penicillin intermediate $(\sim 20 \%)$ and resistant strains $(25 \%)$ is marked. For $H$. influenzae, $\beta$-lactamase production is again high in Spain (35-50\%), with lower rates in France $(25-35 \%)$, the UK $(\sim 20 \%)$ and Belgium $(15 \%)$ [7].

The treatment of lower respiratory tract infection in the community is largely empirical, as identification of the causative pathogen is seldom undertaken. First-line therapies for acute bacterial exacerbations of chronic obstructive pulmonary disease (COPD) commonly include amoxycillin, a cephalosporin or, in some countries, a macrolide. However, as $\leq 25 \%$ of patients return within 1 week, the efficacy of such therapy is questionable [8].

Fluoroquinolone antibiotics have a wide spectrum of activity that covers the common respiratory pathogens $[9$, 10]. However, the perceived limitations of older fluoroquinolones against $S$. pneumoniae have led to a reluctance to use these agents in respiratory tract infection. The newer fluoroquinolones retain the good activity against Gram-negative organisms $[11,12]$ and "atypical" respiratory pathogens of older agents, while providing extended Gram-positive activity. Of particular interest is their 
activity against $S$. pneumoniae, irrespective of penicillin susceptibility, and $\beta$-lactamase-positive and -negative strains of $H$. influenzae and $M$. catarrhalis [1, 13, 14].

The investigation of the clinical relevance of an antibiotic's pharmacodynamic interactions in respiratory tract infection is complicated by infections occurring at a number of distinct sites. In acute bronchitis, acute exacerbations of COPD and bronchiectasis, bacteria are found within the lumen of the airways, at the mucosal cell surface and within the bronchial mucosal tissue. In pneumonia, bacteria are mainly found at alveolar locations. However, in all these infections epithelial lining fluid (ELF) and alveolar macrophages also appear to be important sites of infection. While it seems sensible to direct antibiotic therapy against the core pathogens common to most patients, data on antibiotic penetration to these infection sites are relevant.

This review will consider the pharmacokinetic and pharmacodynamic features of the fluoroquinolones ciprofloxacin, ofloxacin, levofloxacin, lomefloxacin, sparfloxacin, gatifloxacin, trovafloxacin, grepafloxacin and moxifloxacin, and their use in respiratory tract infection.

\section{Methodological considerations}

While serum antibiotic levels are thought to correlate with therapeutic efficacy, antibiotic penetration at the infection site would seem to be a more relevant feature [15], yet there are few data supporting this hypothesis. In urinary tract infections, clinical cure has been demonstrated in situations where serum antibiotic concentrations were sufficiently low to indicate treatment failure [16].

The advent of modern endoscopic procedures has allowed the investigation of antibiotic concentrations at different sites within the respiratory tree. Sputum is now considered an unsuitable fluid for pharmacokinetic studies, as its lack of homogeneity, dilution by saliva, pooling within the respiratory tract and, in addition, the instability of some antimicrobial agents in sputum lead to methodological and interpretational problems. More commonly, penetration is measured in the bronchial mucosa, ELF and alveolar macrophages. Samples of bronchial mucosa are obtained at endoscopic biopsy, and generally comprise submucosa $(53.4 \%)$, ciliated epithelium $(22.3 \%)$, muscle $(17.6 \%)$ and glandular tissue $(7.0 \%)$, with a total water content of $\sim 70 \%$ [17]. ELF and macrophages are accessible by bronchoalveolar lavage.

\section{Fluoroquinolone pharmacokinetics}

Fluoroquinolone antibiotics are rapidly absorbed following oral administration, and generally demonstrate linear kinetics. The pharmacokinetic parameters of the antibiotics studied are shown in table 1 [18-24]. Penetration into body fluids is favourable, as suggested by high volumes of distribution (generally $>150 \mathrm{~L}$ ) and generally low protein binding levels. The absolute bioavailability of fluoroquinolones exceeds $50 \%$ and their long terminal half-lives allow once- or twice-daily dosing regimens [25], with peak serum concentrations being reached within 1-3 h of dosing [26].

Antibiotics eliminated by both renal and nonrenal routes offer advantages in patients with fluctuating renal function, while those with primarily renal elimination seem preferable in patients with complete renal failure because of the convenience of infrequent administration. Ofloxacin, ciprofloxacin, levofloxacin and gatifloxacin are mainly excreted in an unchanged form in the urine. There is a linear relationship between levofloxacin clearance and renal function, such that dose adjustment is needed in patients with moderate-to-severe renal impairment. Grepafloxacin is eliminated primarily through metabolism in the liver via the cytochrome P450 system and is excreted mainly in the faeces, either via bile or transmucosally [27]. Sparfloxacin is eliminated mostly by nonrenal processes, but some dosage adjustment is needed in patients with moderate-tosevere renal dysfunction.

A factor contributing to fluoroquinolone activity is the tissue levels that they attain. The main barrier to antibiotic penetration is the nonfenestrated capillary endothelium separating the capillaries from the submucosa [28]. To penetrate the alveolar space the antibiotic must also cross the alveolar membrane, which is rendered relatively impermeable by the presence of many tight junctions or zonulae occludens $[29,30]$. There is thus a significant barrier between the ELF and the capillary blood supply. Alveolar macrophages may take up antibiotics from the ELF or serum before migrating into the alveolar space. The activity of the newer macrolides and fluoroquinolones against intracellular respiratory pathogens has led to an increased interest in their penetration into macrophages and polymorphs. The levels of penetration of fluoroquinolones into serum and lung compartments are shown in table 2 [31-35].

Table 1. - Pharmacokinetic parameters of fluoroquinolone antibiotics in healthy volunteers

\begin{tabular}{|c|c|c|c|c|c|c|}
\hline Antibiotic & $\begin{array}{l}C \max \\
\mathrm{mg} \cdot \mathrm{L}^{-1}\end{array}$ & $\stackrel{t \max }{\mathrm{h}}$ & $\begin{array}{c}t 1 / 2 \\
\mathrm{~h}\end{array}$ & $\begin{array}{c}\text { AUC } \\
\mathrm{mg} \cdot \mathrm{h} \cdot \mathrm{L}^{-1}\end{array}$ & $\begin{array}{c}\text { Urinary recovery } \\
\%\end{array}$ & $\begin{array}{c}\text { Oral bioavailability } \\
\%\end{array}$ \\
\hline Ciprofloxacin $500 \mathrm{mg}$ & 2.5 & 2.1 & 5.0 & 11.6 & $30-60$ & $70-80$ \\
\hline Ofloxacin $400 \mathrm{mg}$ & 4.4 & $3.5-4.0$ & 5.7 & 36.8 & 73 & $95-100$ \\
\hline Levofloxacin $500 \mathrm{mg}$ & 5.1 & 1.3 & 6.3 & 47.9 & 77 & 99 \\
\hline Lomefloxacin $400 \mathrm{mg} *$ & 4.7 & - & 7.0 & 32.2 & 76 & - \\
\hline Sparfloxacin $200 \mathrm{mg}$ & $0.56 \pm 0.13$ & $3.52 \pm 0.98$ & $18.3 \pm 3.9$ & $16.4 \pm 2.3$ & $5.89 \pm 1.4$ & 90 \\
\hline Gatifloxacin $400 \mathrm{mg} * *$ & 4.2 & 1.5 & 7 & 34.3 & 96 & - \\
\hline Trovafloxacin $200 \mathrm{mg}$ & 2.9 & 0.75 & 7.8 & 24.4 & 5 & $60-85$ \\
\hline Grepafloxacin $400 \mathrm{mg}$ & 1.43 & 1.86 & 12.2 & 14.6 & 11.3 & 72 \\
\hline Moxifloxacin $400 \mathrm{mg}^{+}$ & 1.4 & 1.0 & $8-12$ & 39.0 & 25.0 & "High"\#" \\
\hline
\end{tabular}

Data are presented as mean, range or mean $\pm \mathrm{SD}$. ${ }^{*}$ : data following a single dose; ${ }^{*}$ : from [86]; ${ }^{+}$: unpublished data; ${ }^{*}:$ no specific data available. $C$ max: maximum observed plasma concentration; $t$ max: time taken to reach $C \max ; t 1 / 2$ : terminal elimination half-life; AUC: area under the plasma concentration-time curve. (From [18-24].) 
Table 2. - Serum and tissue levels of fluoroquinolone antibiotics following multiple dosing schedules

\begin{tabular}{|c|c|c|c|c|}
\hline \multirow[b]{2}{*}{ Antibiotic } & \multicolumn{4}{|c|}{ Antibiotic concentration } \\
\hline & $\begin{array}{l}\text { Serum } \\
\mathrm{mg} \cdot \mathrm{L}^{-1}\end{array}$ & $\begin{array}{l}\text { Bronchial mucosa } \\
\mathrm{mg} \cdot \mathrm{kg}^{-1}\end{array}$ & $\begin{array}{l}\text { Epithelial lining fluid } \\
\qquad \mathrm{mg} \cdot \mathrm{L}^{-1}\end{array}$ & $\begin{array}{l}\text { Alveolar macrophages } \\
\mathrm{mg} \cdot \mathrm{L}^{-1}\end{array}$ \\
\hline Ciprofloxacin* & $1.19 \pm 0.16$ & $1.85 \pm 0.27$ & $3.0 \pm 1.05$ & $13.39 \pm 3.53$ \\
\hline Levofloxacin** & 4.1 & 6.0 & 10.9 & 27.7 \\
\hline Lomefloxacin $^{+}$ & $3.34 \pm 0.37$ & $5.38 \pm 0.57$ & $5.94 \pm 0.86$ & $60.62 \pm 8.60$ \\
\hline Sparfloxacin $^{++}$ & $1.2 \pm 0.4$ & $4.4 \pm 3.0$ & $15.0 \pm 8.3$ & $53.7 \pm 38.4$ \\
\hline Trovafloxacin & $1.47 \pm 0.43$ & $1.67 \pm 0.70$ & $10.21 \pm 12.96$ & $34.3 \pm 19.26$ \\
\hline Grepafloxacin $^{\#}$ & $1.23 \pm 0.14$ & $3.60 \pm 0.44$ & $13.87 \pm 2.74$ & $209.03 \pm 40.98$ \\
\hline
\end{tabular}

Data are presented as mean $\pm \mathrm{SD}$. *: $250 \mathrm{mg}$ b.d. for 4 days. Bronchoscopy was performed at a mean of 288.25 min after the final dose. **: $500 \mathrm{mg}$, single oral dose. Bronchoscopy was performed $4 \mathrm{~h}$ after dosing. ${ }^{+}: 400 \mathrm{mg}$ o.d. for 4 days. No information was given about when bronchoscopy was performed. ${ }^{++}: 400 \mathrm{mg}$ loading dose followed by $200 \mathrm{mg} \cdot$ day $^{-1}$ on days 2 and 3. Bronchoscopy was performed 2.5-5 h after dosing. $: 200 \mathrm{mg}$ daily for 4 days. Bronchoscopy was performed $6 \mathrm{~h}$ after the final dose. ${ }^{\#}: 400 \mathrm{mg}$ daily for 4 days. Bronchoscopy was performed $\leq 13 \mathrm{~h}$ after the final dose. Data for gatifloxacin are unpublished and for moxifloxacin are not available. Levels of ofloxacin have not been studied in these tissues. (From [31-35].)

Most studies on tissue antibiotic levels are performed during the steady state, in uninfected individuals. This could result in bias because the pharmacokinetics of antibiotics may be altered in individuals with an infection. It is also possible that tissue penetration at steady state differs from that after a single dose and so several doses may be needed to achieve steady state, which may also affect tissue penetration.

All the study antibiotics penetrate well into the lung tissue, achieving concentrations higher than the corresponding serum levels. Sparfloxacin and grepafloxacin appear to be concentrated avidly by the bronchial mucosa, ELF and alveolar macrophages, with grepafloxacin attaining levels in alveolar macrophages that dramatically exceed serum levels.

\section{Tissue penetration of fluoroquinolones versus other agents}

\section{Macrolides}

The percentage penetration of macrolides into the bronchial mucosa is dependent upon time and the individual drug. Macrolides have been found to concentrate within the ELF, with azithromycin showing a 7-fold and clarithromycin a 5.7-fold increase compared with serum levels. Accumulation within alveolar macrophages is also seen; levels of azithromycin are up to 23-fold and clarithromycin $\sim 70$-fold higher than in serum [36]. Although fluoroquinolones have been found to accumulate throughout the cell, macrolides tend to concentrate in the lysosomes. Accumulation is affected by factors such as $\mathrm{pH}$ and smoking. Decreasing $\mathrm{pH}$ lowers macrolide accumulation [37]. Most agents will rapidly diffuse out of macrophages after removal of the extracellular antibiotic.

\section{$\beta$-Lactams}

$\beta$-Lactam antibiotics penetrate poorly into cells, accumulating in the bronchial mucosa to $35-55 \%$ of the level attained in serum [36]. This finding correlates well with the expected level for agents confined to extracellular fluids. The hydrophilic nature of $\beta$-lactams also leads to poor penetration into the relatively impermeable alveolar space and the ELF, with levels only reaching $20-50 \%$ of serum concentrations [36]. As $\beta$-lactams are acidic they generally do not accumulate in eukaryotic cells, though some uptake may occur over time due to endocytosis and localization in the lysosomes. However, their activity at this site is negligible due to the low $\mathrm{pH}$ [37]. One study found no detectable levels of most $\beta$-lactam agents within alveolar macrophages, the exception being clavulanate $[36,38]$. The overall penetration of $\beta$-lactams was found to be $30 \%$.

\section{Fluoroquinolone pharmacodynamics}

The activities of the fluoroquinolone antibiotics against common respiratory pathogens and intracellular respiratory pathogens (minimum drug concentration inhibitory to $90 \%$ of strains tested MIC90) are shown in table $3[11,20,39$ 45] and table 4, respectively [14, 20, 46-59].

Grepafloxacin is the most active agent against $H$. influenzae (MIC90 $0.008 \mathrm{mg} \cdot \mathrm{L}^{-1}$ ), with ciprofloxacin, sparfloxacin, trovafloxacin and gatifloxacin showing similar activity (MIC90 0.015-0.016 $\mathrm{mg} \cdot \mathrm{L}^{-1}$ ), while lomefloxacin, ofloxacin, moxifloxacin and levofloxacin are the least active compounds (MIC90 0.06-0.12 mg. $\mathrm{L}^{-1}$ ). Grepafloxacin also shows the greatest activity against $M$. catarrhalis (MIC90 $0.015 \mathrm{mg} \cdot \mathrm{L}^{-1}$ ), with ciprofloxacin, levofloxacin, sparfloxacin, gatifloxacin, trovefloxacin and moxifloxacin being equally effective against this pathogen (MIC90 0.03 $\left.\mathrm{mg} \cdot \mathrm{L}^{-1}\right)$. The least active agents are ofloxacin and lomefloxacin (MIC90 $0.12 \mathrm{mg} \cdot \mathrm{L}^{-1}$ ). Against Staphylococcus aureus, trovefloxacin and moxifloxacin have the highest activity (MIC90 $0.06 \mathrm{mg} \cdot \mathrm{L}^{-1}$ ), while sparfloxacin, gatifloxacin and grepafloxacin show similar efficacy (MIC90 0.12$\left.0.13 \mathrm{mg} \cdot \mathrm{L}^{-1}\right)$. Ciprofloxacin and lomefloxacin are the least active (MIC90 $\left.1.0 \mathrm{mg} \cdot \mathrm{L}^{-1}\right)$.

Although ciprofloxacin resistance in $H$. influenzae is seldom seen [60], resistance in Gram-positive respiratory pathogens, such as $S$. pneumoniae to earlier quinolones, such as ciprofloxacin, has been reported in Europe and the USA [61]. It is possible that the newer fluoroquinolones will be active against these resistant strains, and work is currently being undertaken to assess the significance of these observations. Of the agents discussed 
Table 3. - Minimum drug concentration inhibitory to $90 \%$ of tested strains (MIC90) values of fluoroquinolone antibiotics against common respiratory pathogens

\begin{tabular}{|c|c|c|}
\hline Antibiotic & $\begin{array}{l}\text { MIC range } \\
\mathrm{mg} \cdot \mathrm{L}^{-1}\end{array}$ & $\begin{array}{l}\mathrm{MIC} 90 \\
\mathrm{mg} \cdot \mathrm{L}^{-1}\end{array}$ \\
\hline \multicolumn{3}{|c|}{ Streptococcus pneumoniae* } \\
\hline Ciprofloxacin & $0.5-2.0$ & 2.0 \\
\hline Ofloxacin & $1.0-2.0$ & 2.0 \\
\hline Levofloxacin & $0.25-2.0$ & 2.0 \\
\hline Lomefloxacin & $2.0-16.0$ & 8.0 \\
\hline Sparfloxacin & $0.5-1.0$ & 0.5 \\
\hline Gatifloxacin & $0.06-1.0$ & 1.0 \\
\hline Trovafloxacin & $0.03-0.25$ & 0.25 \\
\hline Grepafloxacin & $0.12-0.5$ & 0.25 \\
\hline Moxifloxacin & $0.03-0.25$ & 0.25 \\
\hline \multicolumn{3}{|c|}{ Haemophilus influenzae** } \\
\hline Ciprofloxacin & $0.004-0.03$ & 0.015 \\
\hline Ofloxacin & $0.015-0.06$ & 0.06 \\
\hline Levofloxacin & $0.008-0.06$ & 0.06 \\
\hline Lomefloxacin & $0.06-0.12$ & 0.12 \\
\hline Sparfloxacin & $0.004-0.06$ & 0.015 \\
\hline Gatifloxacin & $0.004-0.016$ & 0.016 \\
\hline Trovafloxacin & $0.004-0.03$ & 0.016 \\
\hline Grepafloxacin & $0.001-0.06$ & 0.008 \\
\hline Moxifloxacin & $0.008-0.13$ & 0.06 \\
\hline \multicolumn{3}{|c|}{ Moraxella catarrhalis*** } \\
\hline Ciprofloxacin & $0.008-0.06$ & 0.03 \\
\hline Ofloxacin & $0.03-0.12$ & 0.12 \\
\hline Levofloxacin & $0.016-0.03$ & 0.03 \\
\hline Lomefloxacin & $0.06-0.12$ & 0.12 \\
\hline Sparfloxacin & $0.013-0.06$ & 0.03 \\
\hline Gatifloxacin & $0.004-0.03$ & 0.03 \\
\hline Trovafloxacin & $0.002-0.03$ & 0.03 \\
\hline Grepafloxacin & $0.004-0.03$ & 0.015 \\
\hline Moxifloxacin & $0.004-0.03$ & 0.03 \\
\hline \multicolumn{3}{|c|}{ Staphylococcus aureus $^{+}$} \\
\hline Ciprofloxacin & $0.06-2.0$ & 1.0 \\
\hline Ofloxacin & $0.12-1.0$ & 0.5 \\
\hline Levofloxacin & $0.06-0.25$ & 0.25 \\
\hline Lomefloxacin & $0.5-4.0$ & 1.0 \\
\hline Sparfloxacin & $0.06-16.0$ & 0.125 \\
\hline Gatifloxacin & $0.03-0.25$ & 0.13 \\
\hline Trovafloxacin & $0.008-0.13$ & 0.06 \\
\hline Grepafloxacin & $0.03-0.12$ & 0.12 \\
\hline Moxifloxacin & $0.016-0.13$ & 0.06 \\
\hline
\end{tabular}

*: Penicillin $=0.06 \mathrm{mg} \cdot \mathrm{L}^{-1}$ for moxifloxacin, gatifloxacin, trovafloxacin and levofloxacin; **: Ampicillin $=8.0 \mathrm{mg} \cdot \mathrm{L}^{-1}$ for moxifloxacin, gatifloxacin, trovafloxacin and levofloxacin; ***: $\beta$-lactamase-positive M.catarrhalis for moxifloxacin, gatifloxacin, trovafloxacin and levofloxacin; ${ }^{+}$: avoid in Methicillinresistant $S$. aureus for moxifloxacin, gatifloxacin, trovafloxacin and levofloxacin. MIC: minimum inhibitory concentration. (From [11, 20, 39-45].)

here, trovefloxacin, grepafloxacin and moxifloxacin are equally active against $S$. pneumoniae (MIC90 0.25 $\left.\mathrm{mg} \cdot \mathrm{L}^{-1}\right)$. Ciprofloxacin, levofloxacin and ofloxacin are around 8-fold less effective (MIC90 $2.0 \mathrm{mg} \cdot \mathrm{L}^{-1}$ ), while lomefloxacin is the least active agent (MIC90 $8.0 \mathrm{mg} \cdot \mathrm{L}^{-1}$ ).

Antibiotic levels achieved in serum and lung tissues have a bearing on therapeutic outcome, and levels of the study antibiotics are generally above the MIC90 for common respiratory pathogens and atypical organisms (table $2)$. However, the serum level of ciprofloxacin $(1.19 \pm 0.16$ $\left.\mathrm{mg} \cdot \mathrm{L}^{-1}\right)$ is below the MIC90 of $S$. pneumoniae $(2.0 \mathrm{mg}$. $\mathrm{L}^{-1}$ ) and borderline for $S$. aureus (MIC90 $1.0 \mathrm{mg} \cdot \mathrm{L}^{-1}$ ).
Table 4. - Minimum drug concentration inhibitory to $90 \%$ of tested strains (MIC90) values for fluoroquinolone antibiotics against atypical pathogens

\begin{tabular}{lc}
\hline Antibiotic & MIC90 $\mathrm{mg} \cdot \mathrm{L}^{-1}$ \\
\hline Chlamydia pneumoniae & \\
Ciprofloxacin & $0.25-4.0$ \\
Ofloxacin & $0.5-2.0$ \\
Levofloxacin & 0.1 \\
Lomefloxacin & 4.0 \\
Sparfloxacin & 0.25 \\
Gatifloxacin & 0.125 \\
Trovafloxacin & 0.006 \\
Grepafloxacin & 0.06 \\
Moxifloxacin & 1.0 \\
Legionella pneumophila & \\
Ciprofloxacin & $0.002-1.0$ \\
Ofloxacin & $0.0157-1.0$ \\
Levofloxacin & 0.1 \\
Lomefloxacin & $0.03-12$ \\
Sparfloxacin & 0.06 \\
Gatifloxacin & - \\
Trovafloxacin & $0.008-0.12$ \\
Grepafloxacin & $0.004-0.125$ \\
Moxifloxacin & 0.125 \\
Mycoplasma pneumoniae & \\
Ciprofloxacin & 1.0 \\
Ofloxacin & 2.0 \\
Levofloxacin & 0.5 \\
Lomefloxacin & 2.0 \\
Sparfloxacin & 0.06 \\
Gatifloxacin & 0.06 \\
Trovafloxacin & 0.25 \\
Grepafloxacin & 0.125 \\
Moxifloxacin & 0.06 \\
\hline *: data for L. pneumophila serogroup $1 .($ From 14 & $20,46-59])$. \\
&
\end{tabular}

Lomefloxacin also demonstrates serum levels (3.34 \pm 0.37 $\mathrm{mg} \cdot \mathrm{L}^{-1}$ ) that are inadequate against $S$. pneumoniae (MIC90 $\left.8.0 \mathrm{mg} \cdot \mathrm{L}^{-1}\right)$.

The newer fluoroquinolones show higher levels of activity against the so-called "atypical" pathogens than older agents. Trovafloxacin (MIC90 $0.006 \mathrm{mg} \cdot \mathrm{L}^{-1}$ ) and grepafloxacin (MIC90 $0.06 \mathrm{mg} \cdot \mathrm{L}^{-1}$ ) are the most active agents against Chlamydia pneumoniae, with levofloxacin, gatifloxacin and sparfloxacin showing comparable efficacy (MIC90 $0.1-0.25 \mathrm{mg} \cdot \mathrm{L}^{-1}$ ). Ofloxacin, ciprofloxacin and lomefloxacin are the least active agents. Similarly, the new quinolones are generally more active than the earlier agents of this class against Mycoplasma pneumoniae. Legionella pneumophila is highly susceptible to most fluoroquinolones.

Area under the curve:minimum inhibitory concentration ratio

While the minimum inhibitory concentration (MIC) is an important measure of a pathogen's antibiotic susceptibility, it is only one of several factors needed to predict the success of therapy. The area under the curve (AUC):MIC ratio (area under the inhibition curve (AUIC) describes the relationship between the pharmacokinetics of an antibiotic and its pharmacodynamic interaction with infecting organisms (fig. 1) [62], and can be considered as a surrogate marker for outcomes, including clinical cure. In vitro and 


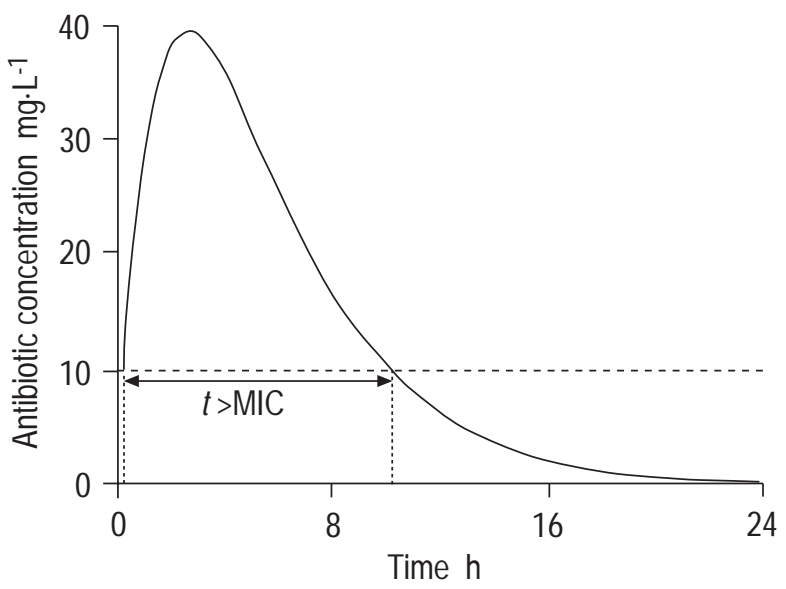

Fig. 1. - Pharmacokinetic surrogate relationships. Area under the inhibition curve $=$ area under the plasma concentration-time curve (AUC)/ minimum inhibitory concentration (MIC, - - - ) $=240$; maximum observed plasma concentration: $\mathrm{MIC}=4$; time that the serum drug concentration exceeds the MIC $(t>\mathrm{MIC})=(10-0.5) \mathrm{h}=9.5 \mathrm{~h}$.

clinical studies have been carried out to investigate relationship between antibiotic exposure and bacterial susceptibility to ciprofloxacin [63]. A threshold area under the inhibition curve over a 24-h period (AUIC24) of 125 was found to be necessary for effective antibiotic activity in both situations and in a study of ciprofloxacin in nosocomial lower respiratory tract infection [64]. An AUIC24 >125 gave a significantly higher rate of microbiological and clinical cure, and at levels $<125$ the microbiological failure rate was $\sim 70 \%$. At an AUIC $24>250$, bacterial killing was rapid, with an average eradication of 1.9 days regardless of species. A further study of ciprofloxacin and strains of $S$. pneumoniae, $S$. aureus and Pseudomonas aeruginosa with MICs of $\sim 0.5$ confirmed that the MIC was predictive of antibacterial activity across bacterial species when an AUIC24 of 250 was achieved [65].

Another analysis that correlates well with the efficacy of fluoroquinolone therapy is the maximum concentration $(C \max )$ :MIC90 ratio. Using ciprofloxacin, enoxacin, norfloxacin, ofloxacin and pefloxacin normalized to a 1-g dose against Escherichia coli, $P$. aeruginosa and $S$. aureus, one study predicted efficacy for drugs with a ratio $>5: 1$ [66]. This represents the serum concentration exceeding the MIC90 for most of a 12-h dosing interval. This analysis may be best suited to fluoroquinolones with a halflife $\geq 5-6 \mathrm{~h}$ and a twice-daily dosing regimen.

\section{Time above the minimum inhibitory concentration}

There is interdependence between pharmacokinetic surrogate markers, such as AUIC, and time above the MIC. With antibiotics that mainly demonstrate time-dependent killing, such as $\beta$-lactams, the aggregate time above the MIC is the surrogate marker most often shown to affect bactericidal activity. AUIC and the $C$ max:MIC ratio are better predictors of efficacy with fluoroquinolones than time above the MIC [64]. A clinical pharmacodynamics study of ciprofloxacin in lower respiratory tract infection found evidence of a correlation between time above the MIC and time to eradication for 14 pathogens [67]. In addition, essentially all pathogens with an MIC $\leq 0.25$ $\mathrm{mg} \cdot \mathrm{L}^{-1}$ were eradicated. In those patients whose pathogens were not eradicated, initial MICs were $\geq 0.5 \mathrm{mg} \cdot \mathrm{L}^{-1}$.

\section{Side-effect profile}

Fluoroquinolones are generally well tolerated, with sideeffects including upper gastrointestinal disturbances, central nervous system (CNS) reactions and phototoxicity (table 5) [20, 68-84]. Some of these effects may be predicted by structure, such that 8-halogenated derivatives (e.g. lomefloxacin and sparfloxacin) are more likely to cause phototoxicity [81]. The newer fluoroquinolones have demonstrated increased activity against various anaerobes, including Clostridium difficile, possibly suggesting a reduced potential for inducing overgrowth of this organism, although this has yet to be demonstrated clinically [85-87].

Prolongation of the QTc interval has been observed with some fluoroquinolones. A very small QTc prolongation of $<2 \mathrm{~ms}$ has been observed in elderly subjects treated with grepafloxacin. In contrast, subjects receiving sparfloxacin have been reported to have a QTc prolongation of 7-11 ms, with $0.7 \%$ of patients having a QTc interval of $>500 \mathrm{~ms}$ (unpublished data). Additionally, prolongation of the QTc interval with sparfloxacin [83] has been associated with a recent episode of torsades de pointes provoking cardiac arrest that led to pulmonary resuscitation in a female with anterior pituitary deficiency [88]. No data on QTc prolongation have been published for the other quinolones discussed, so no assessment is possible and it is therefore premature to draw any conclusions at this stage. A strong temporal relationship has been noted between macrolide administration and the prolongation of the QTc interval (prolongation of myocardial repolarization). In two patients with bronchopneumonia receiving clarithromycin, QTc intervals of $670 \mathrm{~ms}$ and $775 \mathrm{~ms}$ were recorded [89], while a retrospective review of records from patients hospitalized with simple pneumonia found intravenous erythromycin use to be associated with a mean QTc prolongation of $46 \mathrm{~ms}$. The mean QTc interval in this group of patients was $468 \mathrm{~ms}$ [90].

Some quinolones, such as ofloxacin, are more commonly associated with CNS events than others [80]. Preliminary data with trovefloxacin indicate that it is associated with dose-dependent transient dizziness, with a $200 \mathrm{mg}$ dose being associated with dizziness in up to $11 \%$ of patients and light-headedness in 4\% [84].

Certain fluoroquinolones are known to raise serum theophylline levels. Patients taking theophylline should be monitored for signs of theophylline toxicity when it is coadministered with ciprofloxacin [91], and it is appropriate to halve the theophylline maintenance dose in patients receiving grepafloxacin [92]. In addition, staggered dosage regimens are recommended to avoid the reduced bioavailability of ciprofloxacin, ofloxacin and sparfloxacin resulting from the concomitant use of compounds containing multivalent cations such as aluminium or magnesium-based antacids, and sucralfate.

Trovafloxacin has been associated with hepatotoxicity including liver enzyme abnormalities and/or symptomatic hepatitis and, rarely, liver failure [84]. 
Table 5. - Side-effects and drug reactions associated with fluoroquinolone use

\begin{tabular}{|c|c|c|c|c|}
\hline Antibiotic & Side-effect & $\begin{array}{l}\text { Incidence of } \\
\text { phototoxicity }\end{array}$ & Drug interactions & [Ref.] \\
\hline Ciprofloxacin & $\begin{array}{l}\text { Gastrointestinal effects }(5 \%) \\
\text { CNS effects }(1 \%)\end{array}$ & Low & $\begin{array}{l}\text { Theophylline } \\
\text { Caffeine } \\
\text { Compounds containing multivalent } \\
\text { cations (e.g. aluminium - and } \\
\text { magnesium-based antacids) } \\
\text { Sucralfate }\end{array}$ & {$[68,74-78,80]$} \\
\hline Ofloxacin & $\begin{array}{l}\text { Gastrointestinal effects ( } 3 \%) \\
\text { CNS effects }(1 \%) \\
\text { Taste and smell impairment }\end{array}$ & Low & $\begin{array}{l}\text { Slight theophylline interaction } \\
\text { Compounds containing multivalent } \\
\text { cations (e.g. aluminium - and } \\
\text { magnesium-based antacids) } \\
\text { Sucralfate }\end{array}$ & {$[20,72,78,79]$} \\
\hline Levofloxacin & $\begin{array}{l}\text { General incidence } 1-3 \% \\
\text { Mostly mild gastrointestinal } \\
\text { effects }(2 \%)\end{array}$ & - & $\begin{array}{l}\text { Compounds containing multivalent } \\
\text { cations (e.g. aluminium - and } \\
\text { magnesium-based antacids)* }\end{array}$ & {$[71,80]$} \\
\hline Lomefloxacin & $\begin{array}{l}\text { CNS effects }(6 \%) \\
\text { Gastrointestinal effects }(5 \%) \\
\text { Skin reactions }(2 \%)\end{array}$ & Yes & - & {$[80,82]$} \\
\hline Sparfloxacin & $\begin{array}{l}\text { General incidence: } \\
\text { high-dose therapy }(32 \%)^{* *} \\
\text { low-dose therapy }(22 \%)^{* * *} \\
\text { Gastrointestinal effects }(6-10 \%) \\
\text { CNS effects (particularly insomnia } \\
\text { and other sleep disorders) }(>3 \%) \\
\text { Skin reactions }(2 \%) \\
\text { Prolonged QTc interval }(1 \%)\end{array}$ & Yes & $\begin{array}{l}\text { Compounds containing multivalent } \\
\text { cations (e.g. aluminium - and } \\
\text { magnesium-based antacids) } \\
\text { Sucralfate } \\
\text { Ferrous sulphate }\end{array}$ & $\begin{array}{l}{[20,73,78} \\
80,81,83]\end{array}$ \\
\hline Trovafloxacin $^{+}$ & $\begin{array}{l}\text { Dose-dependent, transient } \\
\text { dizziness }(11 \%) \\
\text { Lightheadedness }(4 \%) \\
\text { Nausea }(8 \%) \\
\text { Headache }(5 \%)\end{array}$ & No & $\begin{array}{l}\text { Caffeine }(15 \% \text { increase in } \\
\text { absorption) } \\
\text { Cations (e.g. aluminium - and } \\
\text { magnesium-based antacids) }\end{array}$ & {$[84]$} \\
\hline Grepafloxacin $^{++}$ & $\begin{array}{l}\text { Nausea }(10-12 \%) \\
\text { Diarrhoea }(3 \%) \\
\text { Taste perversion }(4-6 \%)\end{array}$ & Low & $\begin{array}{l}\text { Theophylline } \\
\text { Caffeine } \\
\text { Cations (e.g. aluminium - and } \\
\text { magnesium-based antacids) }\end{array}$ & {$[69,70,77]$} \\
\hline
\end{tabular}
*: levofloxacin data sheet; **: 400-mg loading dose then $200 \mathrm{mg} \cdot$ day $^{-1} \cdot * * *: 200-\mathrm{mg}$ loading dose then $100 \mathrm{mg}^{*}$ day $^{-1} \cdot{ }^{+}: 200-\mathrm{mg}$ dose;
${ }^{++}$: 400-mg dose. CNS: central nervous system; QTc interval: Q-T interval corrected for heart rate.

\section{Clinical impact}

Many physicians in the community do not differentiate between lower respiratory tract infections, treating most patients with antibiotics. Antibiotics have been shown to be more effective than placebo in some patients with acute exacerbations of COPD [93]. There has been some recent work to suggest that quinolones may be useful in reducing the duration and frequency of acute exacerbations of COPD in those patients with $\geq 4$ exacerbations per year [68].

There is some evidence that the antibiotic concentration at the site of infection has a bearing on clinical outcome in respiratory tract infection [94], so it seems reasonable to select an agent that attains high concentrations at such sites over one that does not. Fluoroquinolones are concentrated in the respiratory tree, and clinical trials have found them to be effective in the treatment of respiratory tract infection. In community-acquired pneumonia, grepafloxacin has been shown to be clinically equivalent to amoxycillin, with a statistically superior microbiological eradication rate [69]. It has also proved highly effective in the resolution of both typical and atypical pneumonia [70]. In patients with acute bacterial exacerbations of COPD, grepafloxacin also demonstrated clinical equiva- lence and microbiological superiority to amoxycillin [95]. A study of acute and chronic lower respiratory tract infection found levofloxacin to have a comparable efficacy to ofloxacin [71, 91]. The uptake and avid concentration of the newer fluoroquinolones by alveolar macrophages also extends their use to atypical pathogens [70]. They may also prove beneficial in reducing the incidence of chronic or recurrent respiratory infections which may result from the survival and multiplication of pathogens, such as $S$. aureus and $H$. influenzae, following ingestion by alveolar macrophages.

In studies of community-acquired pneumonia requiring hospitalization, ofloxacin was as effective as the standard regimen of a $\beta$-lactam with or without a macrolide [72], and sparfloxacin has achieved similar outcomes to amoxycillin-clavulanic acid and erythromycin [73]. The use of oral fluoroquinolones in place of intravenous or oral therapy with one or more agents in this setting seems promising. However, further clinical studies are needed. Early studies in hospital-acquired pneumonia have shown that an early switch to oral fluoroquinolone therapy is effective and well-tolerated, possibly because of the high serum and tissue levels achieved [74]. Thus, oral fluoroquinolones may offer the potential to reduce hospital costs [75]. 
Current treatment guidelines for the management of community-acquired respiratory tract infection in adults recommend the fluoroquinolones for empirical therapy in several patient groups. In the guidelines of the European Respiratory Society [3], the newer fluoroquinolones are suggested as alternatives to the use of aminopenicillin in patients with community-acquired lower respiratory tract infection managed at home, whereas the older quinolones (e.g. ciprofloxacin or ofloxacin) are recommended in these patients managed in the hospital setting. Guidelines from the Infectious Diseases Society of America [4] on the management of community-acquired pneumonia in adults state that fluoroquinolones are among the preferred agents for the empirical treatment of such patients in the community and the hospital, and for pathogen-directed therapy.

Most fluoroquinolones reach concentrations in the serum and lung tissues that exceed the MIC90 for many common respiratory pathogens. Thus, they are present at clinically significant levels at all potential sites of respiratory tract infection. The exceptions are ciprofloxacin and lomefloxacin, which both demonstrated serum levels below the MIC90 of $S$. pneumoniae. This may explain the concern felt by many about the incidences of treatment failure and breakthrough infections seen in patients with pneumonia receiving ciprofloxacin [96].

Subtherapeutic levels of ciprofloxacin may also be implicated in the development of pneumococcal ciprofloxacin resistance. The rapid emergence of resistance to newer fluoroquinolones in respiratory pathogens appears unlikely with recent evidence suggesting that some of them may primarily target the deoxyribonucleic acid gyrase A gene (gyrA), rather than parC which is the major target for ciprofloxacin and other older quinolones [97]. Of relevance is the fact that the new fluoroquinolones with high activity against parC mutants, may suppress the first parC mutation, possibly preventing a further mutation leading to high-level resistance [7].

The fluoroquinolones currently available offer major therapeutic advances compared with precursor agents, and the incidence of adverse events is clearly outweighed by their clinical utility. As with other antibiotics the development of resistance is a potential problem associated with their increased use in respiratory tract infection. Rational prescribing and vigilance in monitoring antibiotic resistance levels are needed to perpetuate bacterial susceptibility.

Acknowledgements. The authors undertake many studies for the pharmaceutical industry, including GlaxoWellcome whom they thank for assistance and production of this article.

\section{References}

1. Spangler SK, Jacobs MR, Pankuch GA, Appelbaum PC. Susceptibility of 170 penicillin-susceptible and penicillinresistant pneumococci to six oral cephalosporins, four quinolones, desacetylcefotaxime, RO 23-9424 and RP 7829. J Antimicrob Chemother 1993; 31: 273-280.

2. American Thoracic Society. Guidelines for the initial management of adults with community-acquired pneumonia: diagnosis, assessment of severity, and initial antimicrobial therapy. Am Rev Respir Dis 1993; 148: $1418-1426$.
3. European Study on Community-acquired Pneumonia Committee. Guidelines for management of adult community-acquired lower respiratory tract infections. Eur Respir J 1998; 11: 986-991.

4. Bartlett JG, Breiman RF, Mandell LA, File TM Jr. Guidelines from the Infectious Diseases Society of America. Community-acquired pneumonia in adults: guidelines for management. Clin Infect Dis 1998; 26: 811-838.

5. Appelbaum PC. Antimicrobial resistance in Streptococcus pneumoniae: an overview. Clin Infect Dis 1992; 15: 77-83.

6. Doern GV. Trends in antimicrobial susceptibility of bacterial pathogens of the respiratory tract. Am J Med 1995; 99: 3S-7S.

7. Baquero F. Increasing role of resistance in LRTIs. Infect Med 1998; 15 (Suppl. 1): 16-27.

8. Macfarlane J, Prewett J, Rose D, et al. Prospective casecontrol study of role of infection in patients who reconsult after initial antibiotic treatment for lower respiratory tract infection in primary care. BMJ 1997; 315: 12061210.

9. Neu HC. Use of quinolones. Infect Dis Clin Pract 1992; 1: 1-10.

10. Brueggemann $\mathrm{AB}$, Kugler $\mathrm{KC}$, Doern $\mathrm{GV}$. In vitro activity of BAY 12-8039, a novel 8-methoxyquinolone, compared to activities of six fluoroquinolones against Streptococcus pneumoniae, Haemophilus influenzae, and Moraxella catarrhalis. Antimicrob Agents Chemother 1997; 41: 1594-1597.

11. Bauernfeind A. Comparison of the antibacterial activities of the quinolones Bay 12-8039, gatifloxacin (AM 1155), trovefloxacin, clinafloxacin, levofloxacin and ciprofloxacin. J Antimicrob Chemother 1997; 40: 639-651.

12. Wiedemann B, Heisig P. Antibacterial activity of grepafloxacin. J Antimicrob Chemother 1997; 40 (Suppl. A): $19-25$.

13. Sader HS, Erwin ME, Jones RN. In vitro antimicrobial activity of OPC-17116 compared to other broad spectrum fluoroquinolones. Eur J Clin Microbiol Infect Dis 1991; 11: $372-381$.

14. Wise R, Andrews JM, Brenwald N. The in vitro activity of OPC-17116, a new 5-methyl substituted quinolone. $J$ Antimicrob Chemother 1993; 31: 497-504.

15. Honeybourne D. The penetration of antimicrobial agents into lung tissue. Thorax 1994; 49: 104-106.

16. Stamey TA, Fair WR, Timothy MM. Serum versus urinary antimicrobial concentrations in cure of urinary tract infections. N Engl J Med 1974; 291: 1159-1163.

17. Baldwin DR, Wise R, Andrews JM, Honeybourne D. Quantitative morphology and water distribution of bronchial biopsy samples. Thorax 1992; 47: 504-507.

18. Efthymiopoulos C. Pharmacokinetics of grepafloxacin. $J$ Antimicrob Chemother 1997; 40 (Suppl. A): 35-43.

19. Wise R, Mortiboy D, Child J, Andrews JM. Pharmacokinetics and penetration into inflammatory fluid of trovafloxacin (CP-99, 219). Antimicrob Agents Chemother 1996; 40: 47-49.

20. Goa KL, Bryson HM, Markham A. Sparfloxacin. A review of its antibacterial activity, pharmacokinetic properties, clinical efficacy and tolerability in lower respiratory tract infections. Drugs 1997; 53: 700-725.

21. Nakashima M, Uematsu T, Kosuge K, et al. Single- and multiple-dose pharmacokinetics of AM-1155, a new 6fluoro-8-methoxy quinolone, in humans. Antimicrob $\mathrm{Ag}$ ents Chemother 1995; 39: 2635-2640.

22. Echols R, Weinstein MP, O'Keeffe B, Shah A, Heller AH. Comparative crossover assessment of serum bactericidal activity and pharmacokinetics of ciprofloxacin and ofloxacin. J Antimicrob Chemother 1994; 33: 111-118.

23. Stone JW, Andrews JM, Ashby JP, Griggs D, Wise R. Pharmacokinetics and tissue penetration of orally administered lomefloxacin. Antimicrob Agents Chemother 1988; 32: $1508-1510$. 
24. Ritz M, Lode H, Fassbender M, Borner K, Koeppe P, Nord CE. Multiple-dose pharmacokinetics of sparfloxacin and its influence on fecal flora. Antimicrob Agents Chemother 1994; 38: 455-459.

25. Wolfson JS, Hooper DC. Comparative pharmacokinetics of ofloxacin and ciprofloxacin. Am J Med 1989; 87 (Suppl. 6C): 31S-36S.

26. Wise R, Lockley R, Dent J, Webberly M. Pharmacokinetics and tissue penetration of enoxacin. Antimicrob Agents Chemother 1984; 26: 17-19.

27. Akiyama H, Koike M, Nii S, Ohguro K, Odomi M. OPC17116, an excellently tissue-penetrative new quinolone: pharmacokinetic profiles in animals and antibacterial activities of metabolites. In: Program and Abstracts of the Thirty-First Interscience Conference on Antimicrobial Agents and Chemotherapy, Chicago, IL, 1991. Abstract 1477. Washington, DC, American Society for Microbiology, 1991; pp. 38-39.

28. Wiebel ER. The ultrastructure of the alveolar-capillary barrier. In: Fishman AP, Hecht HH, eds. The Pulmonary Circulation and Interstitial Space. Chicago, The University of Chicago Press, 1969

29. Staehelin LA. Structure and function of intracellular junctions. Int Rev Cytol 1974; 39: 283-287.

30. Williams MC. Conversion of lamellar body membranes into tubular myelin in alveoli of fetal rat lungs. J Cell Biol 1977; 72: 260-277.

31. Baldwin DR, Wise R, Andrews JM, Gill M, Honeybourne D. Comparative bronchoalveolar concentrations of ciprofloxacin and lomefloxacin following oral administration. Respir Med 1993; 87: 595-601.

32. Cook PJ, Andrews JM, Wise R, Honeybourne D, Moudgil $\mathrm{H}$. Concentrations of OPC-17116, a new fluoroquinolone antibacterial, in serum and lung compartments. J Antimicrob Chemother 1995; 35: 317-326.

33. Andrews JM, Honeybourne D, Brenwald NP, et al. Concentrations of trovafloxacin in bronchial mucosa, epithelial lining fluid, alveolar macrophages and serum after administration of single or multiple oral doses to patients undergoing fibre-optic bronchoscopy. J Antimicrob Chemother 1997; 39: 797-802.

34. Andrews JM, Honeybourne D, Jevons G, Brenwald NP, Cunningham B, Wise R. Concentrations of levofloxacin (HR 355) in the respiratory tract following a single oral dose in patients undergoing fibre-optic bronchoscopy. $J$ Antimicrob Chemother 1997; 40: 573-577.

35. Wise R, Honeybourne D. A review of the penetration of sparfloxacin into the lower respiratory tract and sinuses. $J$ Antimicrob Chemother 1996; 37: 57-63.

36. Wise R, Honeybourne D. Antibiotic penetration into the respiratory tract. A basis for rational therapy. J Chemother 1995; 4: 28-32.

37. Tulkens PM. Intracellular distribution and activity of antibiotics. Eur J Clin Microbiol Infect Dis 1991; 10: 100-106.

38. Cook PJ, Andrews JM, Woodcock J, Wise R, Honeybourne D. Concentration of amoxycillin and clavulanate in lung compartments in adults without pulmonary infection. Thorax 1994; 49: 1134-1138.

39. Barry AL, Fuchs PC. Antibacterial activities of grepafloxacin, ciprofloxacin, ofloxacin and fleroxacin. JChemother 1997; 9: 9-16.

40. Eliopoulos GM. In vitro activity of fluoroquinolones against Gram-positive bacteria. Drugs 1995; 49 (Suppl. 2): 48-57.

41. Pankuch GA, Jacobs MR, Appelbaum PC. Activity of CP 99,219 compared with DU-6859a, ciprofloxacin, ofloxacin, levofloxacin, lomefloxacin, tosufloxacin, sparfloxacin and grepafloxacin against penicillin-susceptible and -resistant pneumococci. J Antimicrob Chemother 1995 35: 230-232.

42. Wise R, Andrews JM, Ashby JP, Matthews RS. In vitro activity of lomefloxacin, a new quinolone antimicrobial agent, in comparison with those of other agents. Antimicrob Agents Chemother 1988; 32: 617-622.

43. Hoogkamp-Korstanje TAA. In-vitro activities of ciprofloxacin, levofloxacin, lomefloxacin, ofloxacin, pafloxacin, sparfloxacin and trovefloxacin against Gram-positive and Gram-negative pathogens from respiratory tract infections. J Antimicrob Chemother 1997; 40: 427-431.

44. Wise R, Andrews JM. The activity of grepafloxacin against respiratory pathogens in the UK. J Antimicrob Chemother 1997; 40 (Suppl. A): 27-30.

45. Barry AL. In vitro activities of OPC-17116 and five other fluoroquinolones. 32nd Interscience Conference on Antimicrobial Agents and Chemotherapy, 1992. Abstract 479.

46. Gooding BB, Jones RN. In vitro antimicrobial activity of CP-99,219, a novel azabicyclonaphthyridone. Antimicrob Agents Chemother 1993; 37: 349-353.

47. Neu HC, Chin N-X. In vitro activity of the new fluoroquinolone CP-99,219. Antimicrob Agents Chemother 1994; 38: 2615-2622.

48. Neu HC, Chin N. In vitro activity of S-ofloxacin. Antimicrob Agents Chemother 1989; 33: 1105-1107.

49. Roblin PM, Hammerschlag MR. Activity of a new quinolone BAY 12-8039 against $C$. pneumoniae in vitro. 36th Interscience Conference on Antimicrobial Agents and Chemotherapy, 1996. Abstract F011.

50. Miyashita N, Niki Y, Kishimoto T, Nakajima M, Matsushima T. In vitro and in vivo activities of $\mathrm{AM}-1155$, a new fluoroquinolone, against Chlamydia spp. Antimicrob Agents Chemother 1997; 41: 1331-1334.

51. Ishida $\mathrm{K}$, Kaku $\mathrm{M}$, Irifune $\mathrm{K}$, et al. In vitro and in vivo activity of a new quinolones AM-1155 against Mycoplasma pneumoniae. J Antimicrob Chemother 1994; 34 : 875-883.

52. Kenny GE, Cartwright FD. Susceptibilities of Mycoplasma hominis, Mycoplasma pneumoniae and Ureaplasma urealyticum to a new quinolone, OPC 17116. Antimicrob Agents Chemother 1993; 37: 1726-1727.

53. Kaku M, Ishida $\mathrm{K}$, Irifune $\mathrm{K}$, et al. In vitro and in vivo activities of sparfloxacin against Mycoplasma pneumoniae. Antimicrob Agents Chemother 1994; 38: 738-741.

54. Kenny GE, Cartwright FD. Susceptibilities of Mycoplasma hominis, Mycoplasma pneumoniae and Ureaplasma urealyticum to a new quinolone, trovefloxacin (CP-99,219). Antimicrob Agents Chemother 1996; 40: 1048-1049.

55. Focht J. In vitro activity of BAY 12-8039 compared with other fluoroquinolones against bacterial strains from upper and lower respiratory tract infections in general practice. 2nd European Congress on Chemotherapy/7th BICON, 1998. Abstract T-161.

56. Ruckdeschel G, Lob S, Dalhoff A. In vitro activity of a new 8-methoxyquinolone, BAY 12-8039, against Legionella spp. in comparison to ciprofloxacin, erythromycin and rifampicin. 36th Interscience Conference on Antimicrobial Agents and Chemotherapy, 1996. Abstract F007.

57. Ridgway GL, Salman H, Robbins MJ, Dencer C, Felmingham D. The in-vitro activity of grepafloxacin against Chlamydia spp., Mycoplasma spp., Ureaplasma urealyticum and Legionella spp. J Antimicrob Chemother 1997; 40 (Suppl. A): 31-34.

58. Dubois J, St-Pierre C. In vitro susceptibility study of grepafloxacin and five other antibiotics against Legionella species. 37th Interscience Conference on Antimicrobial Agents and Chemotherapy, 1997; Abstract E30.

59. Roblin PM, Montalban G, Hammerschlag MR. In vitro activities of OPC-17116, a new quinolone; ofloxacin; and sparfloxacin against Chlamydia pneumoniae. Antimicrob Agents Chemother 1994; 38: 1402-1403.

60. Campos J, Roman F, Georgiou M, et al. Long-term persistence of ciprofloxacin-resistant Haemophilus influenzae in patients with cystic fibrosis. J Infect Dis 1996; 174: 1345-1347. 
61. Goldstein FW, Acar JF \& The Alexander Project Collaborative Group. Antimicrobial resistance among lower respiratory tract isolates of Streptococcus pneumoniae: results of a 1992-93 Western Europe and USA collaborative surveillance study. J Antimicrob Chemother 1996; 38 (Suppl. A): 71-84.

62. Hyatt JM, McKinnon PS, Zimmer GS, Schentag JJ. The importance of pharmacokinetic/pharmacodynamic surrogate markers to outcome. Focus on antibacterial agents. Clin Pharmacokinet 1995; 28: 143-160.

63. Schentag JJ, Nix DE, Adelman MH. Mathematical examination of dual individualization principles (I): relationships between AUC above MIC and area under the inhibitory curve for cefmenoxime, ciprofloxacin, and tobramycin. DICP Ann Pharmacother 1991; 25: 10501057

64. Forrest A, Nix DE, Ballow CH, Goss TF, Birmingham $\mathrm{MC}$, Schentag JJ. The pharmacodynamics of intravenous ciprofloxacin in seriously ill patients. Antimicrob Agents Chemother 1993; 37: 1073-1081.

65. Hyatt JM, Nix DE, Schentag JJ. Pharmacokinetics and pharmacodynamics of ciprofloxacin against similar MIC strains of S. pneumoniae, $S$. aureus and $P$. aeruginosa using kill curve methodology. Antimicrob Agents Chemother 1994; 38: 2730-2737.

66. Nix DE, Schentag JJ. The quinolones: an overview and comparative appraisal of their pharmacokinetics and pharmacodynamics. JClin Pharmacol 1988; 28: 169-178.

67. Nix DE, Sands MF, Peloquin CA, et al. Dual individualization of intravenous ciprofloxacin in patients with nosocomial lower respiratory tract infections. Am J Med 1987; 82 (Suppl. 4A): 352-356.

68. Grossman R, Mukherjee J, Vaughan $\mathrm{D}$, et al., for the Canadian Ciprofloxacin Health Economic Study Group. A 1-year community-based health economic study of ciprofloxacin $v s$ usual antibiotic treatment in acute exacerbations of chronic bronchitis. Chest 1998; 113: 131-141.

69. O'Doherty B, Dutchman DA, Pettit R, Maroli A. Randomized, double-blind, comparative study of grepafloxacin and amoxycillin in the treatment of patients with community-acquired pneumonia. $J$ Antimicrob Chemother 1997; 40 (Suppl. A): 73-81.

70. Topkis S, Swarz H, Breisch SA, Maroli AN. Efficacy and safety of grepafloxacin, $600 \mathrm{mg}$ q.d. for 10 days, in patients with community-acquired pneumonia. Clin Ther 1997; 19: 975-989.

71. File TM Jr, Segreti J, Dunbar L, et al. A multicenter, randomized study comparing the efficacy and safety of intravenous and/or oral levofloxacin versus ceftriaxone and/or cefuroxime axetil in treatment of adults with community-acquired pneumonia. Antimicrob Agents Chemother 1997; 41: 1965-1972.

72. Plouffe JF, Herbert MT, File TM Jr, et al. Ofloxacin versus standard therapy in treatment of community-acquired pneumonia requiring hospitalization. Antimicrob Agents Chemother 1996; 40: 1175-1179.

73. Lode H, Garau J, Grassi C, et al. Treatment of community-acquired pneumonia: a randomized comparison of sparfloxacin, amoxycillin-clavulanic acid and erythromycin. Eur Respir J 1995; 8: 1999-2007.

74. Khan FA, Basir R. Sequential intravenous-oral administration of ciprofloxacin versus ceftazidime in serious bacterial respiratory tract infections. Chest 1989; 96: 528537.

75. Paladino JA, Sperry HE, Backes JM, et al. Clinical and economic evaluation of oral ciprofloxacin after an abbreviated course of intravenous antibiotics. Am J Med 1991; 91: 462-470.

76. Davis R, Markham A, Balfour JA. Ciprofloxacin: an updated review of its pharmacology, therapeutic efficacy and tolerability. Drugs 1996; 51: 1019-1074.
77. Ferguson J, Dawe R. Phototoxicity in quinolones: comparison of ciprofloxacin and grepafloxacin. J Antimicrob Chemother 1997; 40 (Suppl. A): 93-98.

78. Christ W, Esch B. Adverse reactions to fluoroquinolones in adults and children. Infect Dis Clin Pract 1994; 3 (Suppl. 3): S168-S176.

79. Jungst G, Mohr R. Overview of post-marketing experience with ofloxacin in Germany. J Antimicrob Chemother 1988; 22 (Suppl. C): 167-175.

80. Ball P, Tillotson G. Tolerability of fluoroquinolone antibiotics. Past, present and future. Drug Saf 1995; 13: 343358.

81. Rubinstein E. Safety profile of sparfloxacin in the treatment of respiratory tract infections. $J$ Antimicrob Chemother 1996; 37 (Suppl. A): 145-160.

82. Rizk E. The US clinical experience with lomefloxacin, a new once-daily fluoroquinolone. Am J Med 1992; 85 (Suppl. 4A): 130S-135S.

83. Jaillon $\mathrm{P}$, Morgauroth $\mathrm{J}$, Brumpt $\mathrm{I}$, et al. Overview of electrocardiographic and cardiovascular safety data for sparfloxacin. J Antimicrob Chemother 1996; 37 (Suppl. A): $161-167$.

84. Trovan $^{\mathrm{TM}}$ tablets and Trovan ${ }^{\mathrm{TM}}$ I.V., US Prescribing Information 1997; Pfizer Inc.

85. Furet YX, Pechere JC. Newly documented antimicrobial activity of quinolones. Eur J Clin Microbiol Infect Dis 1991; 10: 249-254.

86. Spangler S, Jacobs M, Appelbaum P. Activity of CP 99,219 compared with those of ciprofloxacin, grepafloxacin, metronidazole, cefoxitin, pipericillin, and pipericillint-azobactam against 489 anaerobes. Antimicrob Agents Chemother 1998; 38: 2471-2476.

87. Appelbaum P. Quinolone activity against anaerobes: microbiological aspects. Drugs 1995; 49 (Suppl. A): 7680.

88. Dupont H, Timsit JF, Souweine B, Gachot B, Wolff M, Regnier B. Torsades de pointes probably related to sparfloxacin. Eur J Clin Microbiol Infect Dis 1996; 15: 350351.

89. Lee KL, Jim M-H, Tang SC, Tai Y-T. QT prolongation and torsade de pointes associated with clarithromycin. $\mathrm{Am}$ J Med 1998; 104: 395-396.

90. Freeman J, Platt R. Erythromycin prolongs the QTc interval among patients with pneumonia. Pharmacoepidemiol Drug Safety 1997; 6: 13-19.

91. Davis R, Bryson HM. Levofloxacin. A review of its antibacterial activity, pharrnacokinetics and therapeutic efficacy. Drugs 1994; 47: 677-700.

92. Efthymiopoulos C, Bramer SL, Maroli A, Blum B. Warfarin and theophylline interaction studies with grepafloxacin. Clin Pharmacokinet 1997; 33 (Suppl. 1): 39-46.

93. Anthonisen NR, Manfreda J, Warren CPW, Hershfield ES, Harding GKM, Nelson NA. Antibiotic therapy in exacerbations of chronic obstructive pulmonary disease. Ann Intern Med 1987; 106: 196-204.

94. Honeybourne D, Baldwin D. The site concentrations of antimicrobial agents in the lung. J Antimicrob Chemother 1992; 30: 249-260.

95. Langan CE, Cranfield R, Breisch S, Pettit R. Randomized, double-blind study of grepafloxacin versus amoxycillin in patients with acute bacterial exacerbations of chronic bronchitis. J Antimicrob Chemother 1997; 40 (Suppl. A): 63-72.

96. Cooper B, Lawlor M. Pneumococcal bacteremia during ciprofloxacin therapy for pneumococcal pneumonia. $\mathrm{Am} J$ Med 1989; 87: 475.

97. Pan X-S, Fisher LM. Targeting of DNA gyrase in Streptococcus pneumoniae by sparfloxacin: selective targeting of gyrase or topoisomerase IV by quinolones. Antimicrob Agents Chemother 1997; 45: 471-474. 